\title{
MULTI-CULTURAL VALUES AND BORDERS
}

\author{
Basia Nikiforova \\ Department of Ethics, Institute of Culture, Philosophy and Art, \\ Saltoniškių g. 58, LT-08105 Vilnius, Lithuania \\ E-mail: bnikiforova@gmail.com
}

\begin{abstract}
The presumption of this paper is the view of multi-culturalism as a concept grounded on an assumption, rather than data, and legitimized by proclamation, rather than legislation. Multi-culturalism as a socio-political construction is not only "a multi-cultural and multi-religious mosaic", but it has its own values. The new borders inside the European Union (EU) are non-territorial, which confirms the new paradigm about the weakening factor of territorial belonging as such. Nowadays, values become a more and more powerful source of demarcation. The aim of this article is to challenge the problem and its consequences for the identity and perception of values in the new European situation, in which borders are merely symbolic. Multi-culturalism is the revalorization of ethnocentric tradition and the creation of post-materialist values such as individual self-expression, personal transformation, openness and solidarity to others, gender and racial equality, greater tolerance for an ethnic, cultural and religious diversity.
\end{abstract}

Keywords: multi-culturalism, multi-cultural polices, multi-cultural values, religious borders, religious pluralism.

DOI: $10.3846 / 2029-0187.2009 .1 .26-38$

\section{Introduction}

The EU is founded on such values as the respect for human dignity, basic rights, including the rights of communities and individuals for freedom, democracy, equality and the rule of law. These values are common for European societies in which pluralism, non-discrimination, tolerance, justice, solidarity, responsibility and equality between women and men prevail. Europe is undergoing a considerable demographic, economic, cultural and socio-political change. National identities have been challenged by simultaneous processes of the European integration and the migration of people into and across Europe. The new borders inside the EU are non-territorial, the fact which confirms the new paradigm about the weakening factor of territorial belonging as such. Values start to be the more powerful source of demarcation. Globalization has increased the contacts between people and their values, ideas and styles of life in unprecedented ways. Many people perceive this new diversity as exciting, for some it is, however, disempowering and raises fears as potential source of their country's fragmentation, lost of values and the local culture. The fears come to a head over investment, trade, media, cosmopolitan activity and migration policies. In this paper we will try to analyze certain stereotypes about multi-cultural values, different kind of their formation and development in the post-modern society. 
Multi-culturalism as a political and social construction, is not only "multi-cultural and multi-religious mosaic", but it has its own values which are being formed today. In every society, the local national minorities and immigrants were and are a source of cultural and religious differentiation. Religion has been also seen as a historically and contemporarily important facet of the cultures of people arriving in Europe. This differentiation is connected with the situation, in which the potential sources of immigrants are culturally distinct from the traditional European cultures, values and perception of democracy. Among the more appreciable distinctions are the relations between an individual and a group (family), the social status of a woman and a daughter in a family, and a public demonstration of religious beliefs which are centered on the patriarchal religious law.

For this reason, the identity support of local national minorities and immigrants needs different mechanisms of implementation.

The general hypotheses of this article are the following:

Civilization is, first of all, a system of values which is defined by a dichotomy of values in relation to the person, society and nature. Today, the civilization borders pass through the system of values;

Multi-culturalism as a social construct and a theory of the global demographic and ethnic migration and mutation, is a hot subject of investigations held by social theorists and practitioners;

During the last decade a new kind of border was created, dividing the European countries into alternative models of the multi-cultural process, managing: individual pluralism and assimilation system (France), communitarian pluralism (Great Britain, Netherlands), the "guest-workers" system (Germany) and the system of social welfare and social support (Sweden);

Results of these alternative models are different and very discussible, but at the same time offer the possibility to observe the fruits of the upbringing and educating of the new generation.

Most apparent changes in the system of values of the new generation concern cultural, racial and religious tolerance, ecological anxiety and the spread of "postmaterialism".

\section{Religious pluralism as such}

Nowadays, conflicts take place in the situation of religious pluralism which is a part of a multi-cultural tendency. Multi-culturalism as the framework of religious studies has two distinct concepts: the first assumes that multi-culturalism stems from a learning process and it is a part of the culture of a society or social group; the second concept is based on the idea of multi-culturalism as the cultural stage which involves a global sense of place, a trans-local culture and a distinctive mixture of both wider and more local social relations and networks. The term "religious pluralism" can refer to the diversity of religious movements within a particular geographic area, and the theory that there are more than one or more than two kinds of ultimate reality and/or truth; 
and that, therefore, more than one religion can be said to posses the truth, even if their essential doctrines are mutually exclusive. Religious pluralism refers to theological attempts to overcome religious differences between various religions, as well as the attempts to overcome religious differences within different denominations of the same religion.

Pluralism with the presence of various national, religious and cultural traditions already eases the idea and situation of the dominant uniform value system, which has the ideological, legal, religious, and ethnic purposes. In the conditions of globalization, religious and cultural pluralism objectively becomes the most favorable ground for the prosperity of the global, social, cultural and moral tendencies. Religious and cultural pluralism is connected to some secular tendencies. It is not possible to isolate the religious factor from the economical, political and social changes taking place in the rest of the society. If we happen to analyze them, we will find out that fascination with a religion, or, on the contrary, indifference to it, is a part of the wider process, and the religious pluralism, as a part of diversity, has a strong connection with the common opportunity to choose from a big multiplicity of political, cultural and lifestyle preferences. Whenever religion is involved in the process of diversity, these challenges are multiplied. Religious beliefs and practices may be personal and private, but they cannot be easily separated from questions about values.

Many religious leaders are very upset with the conflict of values. In the declaration of "Joint Committee for Dialogue..." both sides ask in what way recognition of such "noble principles and exemplary values" as "peace, truth, justice, and right behavior and co-operation in the development and use of the Earth's resources for the benefit of the whole of humanity", may co-exist with the phenomenon of violence, extremism and terrorism, together with a contempt for religions, religious values and everything that is considered sacred. The recommendations included an appeal to the communications media "to be vigilant that freedom of expression should not be taken as a pretext for offending religions, convictions, religious symbols and everything that is considered sacred". The recommendations also included invitation for religious leaders, intellectuals and educators that they "should make every effort to inculcate these values in their activities in places of learning and in all levels of society"1.

The EU represents a system of values that links peoples and nations together and provides them with identity. The European identity is not a static and final situation but a dynamic, open process, in which members of the European society agree on common perceptions of themselves and others. Changes in national, cultural and religious identities, which are taking place in the pluralistic Europe, are evident and progressive. For Grace Davie, identity is "a moving target" which is changing day by day. Many researchers define identity as "weakening", "disappearing” etc., which suggests a negative undertone of the process and inevitably cannot be comprehensive.

\footnotetext{
${ }^{1}$ Final Declaration of Annual Meeting of The Joint Committee for Dialogue with Monotheistic Religions of al-Azhar (Cairo, 25-26.02.2008), Available from Internet: <http://www.vatican.va/roman_curia/pontifical_councils/interelg/documents/rc_pc_interelg_doc_20090225_final-decl-rome_en.html> [Last access: 06.01.2009].
} 
Identity is a broad term which describes the general aspects of an individual's total personality, that is, the establishment, assimilation or integration of societal norms, values, beliefs and standards. Identity is determined by the intra-personal, inter-personal and environmental characteristics, and interactions of significant components of an individual's unique world. Language, religion, history, clothing, customs, ceremonies and cuisine are just some of the areas that define cultural identity. As Amy Gutmann adds, "identity groups are politically significant associations of people who are identified by or identify with one or more shared social markers. Gender, race, class, ethnicity, nationality, religion, disability, and sexual orientation are among the most obvious examples of shared social markers, around which informal and formal identity groups form" (Gutmann 2003: 8).

We can find some changes of identity borders: the weakening factor of territorial belonging, the mass distribution of the people living in diasporas, the demarcation of identity through the own racial and continental belonging and the strengthening of the Muslim factor, leading to the Europeans' stronger perception of themselves as Christians.

\section{Some stereotypes about multi-cultural values}

The controversy that surrounds universal principles versus multi-cultural values has intensified greatly over the last decade. Nearly every journal in law, philosophy, ethics, political science and sociology now regularly publishes articles on issues of multicultural values and cultural identity. Most of them understand multi-culturalism as a social-intellectual movement that promotes the value of diversity as a core principle and insists that all cultural groups be treated with respect as equals. Generally, multiculturalism can variously be understood as "a way of describing the actual make-up of a society; a general vision of the way government and society should orient itself; a specific set of policy tools for accommodating minority cultural practices" (Vertovec, Wessendorf 2004: 14). At the same time, researchers focus multi-culturalism on two levels: on general principles and philosophies of cultural diversity and more concretely on specific aspects of diversity such as religion and language.

The concept of the universal values, usually expressed in terms of universal human rights, is based on the notion that there is a universal human nature that creates a moral requirement to treat human beings in a certain way simply by virtue of being human. The moderate position is that some human rights standards are universal and must be respected by all people, and that there is an overlapping of values which can be used to establish a common core of Human Rights. Some negative stereotypes about values in the context of multi-culturalism today exist in the research literature and public discussion. The most popular of them are the following:

Multi-culturalism destroys the traditional system of values as such and creates nothing in exchange;

Multi-culturalism is grounded on relativism and rejects values as such; 
Multi-culturalism destroys ethnocentrism, making it a changeable construction function, which is narrow and pragmatic, on which any foundations for new identity creation could not be laid;

Multi-culturalism, as the lack of common standards and values, leads to personal disorganization, resulting in unsociable behavior;

Multi-culturalism is a source of deviant behavior and habits.

Sometimes, the stereotypes about values in the context of multi-culturalism are completed by common myths about influence of ethnic groups on the clash of values. The United Nations (UN) "Human Development Report 2004" described and discussed some of them:

People's ethnic identities compete with their attachment to the state, so there is a trade-off between recognizing diversity and unifying the state;

Ethnic groups are prone to violent conflicts with each other in clashes of values, so there is a trade-off between respecting diversity and sustaining peace;

Cultural liberty requires defending of traditional practices, so there could be a trade-off between recognizing the cultural diversity and other human development priorities such as progress in development, democracy and human rights;

Ethnically diverse countries are less able to develop, so there is a trade-off between respecting diversity and promoting development;

Some cultures are more likely to make the developmental progress than others, and some cultures have inherent democratic values while others do not.

"The Human Development Report 2004", rejected each of these five myths and reasoned this answer in the following way: a sense of identity and belonging to a group with shared values is important to individuals, but each individual can identify with many different groups; cultural liberty is not about preserving values and practices, and culture is not a frozen set of values and practices; there is no evidence of a clear relationship between cultural diversity, culture and economic progress or democracy. The essence of the cultural liberty is the freedom to choose identities and to live in harmony with one's values without being deprived of the possibility to make other significant decisions. "The idea of changing values is at the heart of interpretations of almost every aspect in political change in Western Europe" (van Deth, Scarbrough 1998b: 527). At the same time, it is difficult to find a close or direct connection between the level of moral values orientation and the level of religious belief in a society. From the view of Wolfgang Jagodzinski and Karel Dobbelaere, if the image of God is becoming more abstract, then it is not the abstract value orientation which is changing, but the content of a specific belief, thus we have a clear distinction between religious beliefs and moral convictions. "If all measures of church religiosity and all moral beliefs are seen as multiple indicators of the same latent value orientation, it would be impossible, or at least extremely difficult, to specify and test these hypotheses" (Jagodzinski, Dobbelaere 1998: 218). For them, philosophers have not only eternalized values, but also have established the independent reality of values alongside the physical world and have derived systems of values from metaphysical assumptions. 


\section{Changing values}

Traditional grasp of a problem sees origins of multi-cultural values in multi-cultural society. It is possible to say that the border between national and multi-cultural values go across the oceans (USA, Canada and Australia). In afore-said countries the formatted cultural policy and multi-cultural system of education constitutes a reaction to immigration as a historical source of state's creation. The EU demonstrated another level of multi-culturalism, which was grounded on historical consequences of monocultures and the homogenous past of European states. Multi-cultural values are not historically implanted in most European countries and are only voluntarily accepted obligations. The economic recession has brought xenophobia back to the forefront of the European agenda. Many multi-cultural values were and still are in conflict with traditional national values and start to be the fount of new images of xenophobia. In this sense xenophobia is mainly a psychological issue, the struggle arising from the necessity of defense of the traditional values and national identity.

At the same time, much research on the values and value change during the last twenty years focused on the claim, that advanced industrial societies are in the process of moving from materialist to post-materialist value orientations. This claim is largely associated with the name of Ronald Inglehart and his famous work "Modernization and Postmodernization: Cultural, Economic, and Political Change in 43 Societies" (Inglehart 1997). Along with traditional value orientations, such as authoritarianism, deference, conservatism, progressiveness, religiosity, and materialism; new value orientations such as post-materialism, environmentalism, post-modernism and feminism can be found. The observation of research literature has provided us with three central value orientations antinomies: materialism-postmaterialism, individualismegalitarianism and religious-secular orientations. The change from materialist to postmaterialist value orientations was identified as a "silent revolution", which brought new societal changes to the society of nowadays. For Inglehart, "advanced industrial society leads to a basic shift in values, de-emphasizing the instrumental rationality that characterized industrial society". Many researchers add that this process started at the beginning of the 1960s, when the advanced industrial democracies witnessed a major change in the kinds of issues which was framed on the intellectual level as post-modernism. For Jan W. van Deth and Elinor Scarbrough, "post-modernist value orientations" mean first of all that "the movement from pre-modern to modern and then to post-modern society as a developmental process in which trust, confidence, and loyalty change" (van Deth, Scarbrough 1998a: 21). Post-modern values emphasize self-expression instead of deference to authority and tolerance for other groups.

Scott C. Flanagan and Aie-Rie Lee concluded, that "post-modernists espoused libertarian values, leading them to push for new freedoms and to press to put into law the liberty to adopt new lifestyles, make new kinds of personal choices, and to experiment with and try on the experiential consequences of differing worldviews and values systems" (Flanagan, Lee 2003: 250). To their opinion, "new kinds of personal choices" refer to phenomenon such as legalization of drugs, free sex, abortion, nofault divorce, the liberalization of restrictions on pornography and any kind of censor- 
ship of free expression, women's liberation, minority rights, environmental protection, world peace and the separation of church and state, taking religious education out of the schools.

The borders between pre-modern, modern and post-modern values are not clearly defined. These new borders between personal choices open intensive public discussion and divide the European society. Today, even tolerance as a non-discussible value for Euro-Atlantic world has many different means and accents in Holland, England, France, Germany, Poland and Lithuania. It is focused on different contemporary realms: religions, ethnic minorities, immigrants, sexuality. Different modalities of tolerance are connected with the possibility of constant communication with others, dialogue with dissimilar opinions and an opportunity to look at oneself from an alternative position. Tolerance in this particular case could be identified with respect to the position of "Other" in combination with the purpose of a mutual change of positions (and even in some cases a change of individual and cultural identity) as a result of critical dialogue. Tolerance is not a universal and transcendent moral principle that must be applied uniformly, but a process that has had discrete expressions in different times in history and in different local political and cultural contexts.

In the line of such definitions as multi-cultural and post-modern values, the words "cosmopolitism" and "cosmopolitan values" play an important role. Foregoing definitions are noteworthy because of other aspects: cosmopolitism is hostile to every border, particularly geographical. Cosmopolitanism means that people conceive the world as a whole, adopt universal ethics and exhibit a stance of openness towards people from other places and cultures. Furthermore, cosmopolitans have often been characterized as individuals who have gone physically and cognitively beyond their origins and who represent a specific cultural type, or as people who feel comfortable in many different cultural settings (Hannerz 1990). People with cosmopolitan attitudes and values are characterized by their recognition of others because of their value and integrity as human beings, quite independently of their national affiliations. They share an open and tolerant world view that is not bound by national categories but is based on an awareness of our increasing economic, political and cultural inter-connectedness. We will pay particular attention to the relation between "cosmopolitism" and "europeanization" for the reason that the last process is real, mass and developing within our sight. Although we confine ourselves to mention they are not synonyms: "europeanization" is not a process without external frontiers and limits. "Europeanization" in our context means the process, in which a subject adopts a number of European features and is not automatically equated with the spreading of cosmopolitan values. European and cosmopolitan values have common features: as source of self-identification they are elite enough, mostly connected with specific narrow segments of a society, and with professional groups. From Ulrich Beck's “cosmopolitan vision”, what Europe needs is the courage to unite forms of life which have grown out of language, skin color, nationality or religion with awareness that, in an insecure world, all are equal and everyone is different. 


\section{The case of Finland}

Modern multi-culturalism in Finland is a very new phenomenon, although this country has a long history of Swedish and Russian cultural influences. Multi-culturalism has become a reality in the Finnish society during the last 15 years. In 1990, there were 26255 immigrants in Finland, and by the end of 2005 the number had increased up to 113852 . Today, approximately $3 \%$ of the country's population is immigrants (Matinheikki-Kokko, Pitkänen 2002: 49). Among Finish legal acts there is one titled a Non-Discrimination Act (L21/2004). Its purpose is to foster and safeguard equality in the society. The Act prohibits discrimination based on age, ethnic or national origin, language, religion, beliefs, opinions, health, disability and sexual orientation. Multi-culturalism, as an education process and policy, is a new vague term. Immigration started to increase markedly and the schooling system, which was based on the idea of cultural homogeneity produced through national pedagogy, faced a new situation. "Finnishness as a self-evident framing came into question" (Lappalainen 2006: 100). The discourse of tolerance and multi-cultural values is currently of great social import. In a situation where the idea of cultural homogeneity as a tacit framework rapidly collapsed, the educational discussion adopted a liberal version of multi-culturalism. Sirpa Lappalainen adds that this liberal version of multi-culturalism operates in a specific situation of the country with a relatively small level of immigration and ethnic diversity. From her point of view, "that liberal multi-culturalism turns out to be an exclusive practice. It operates to strengthen, rather than to widen, boundaries of the nation-space as a social and mental construction" (Lappalainen 2006: 100).

Multi-cultural values were the direct subject of Helena Helve's sociologic research at the end of the 90 's ${ }^{2}$. She concluded that in a modern "mono-cultural" homogenous society (such as Finland) young people are free to change their national mono-cultural values to inter-national multi-cultural values, according to the situation. She adds that in Nordic countries such as Finland, the debate about multiculturalism has been raised by multi-cultural education, and that multi-culturalism is a part of the culture of the society or a social group. She searches for an answer to the question: what is multi-culturalism in young people's everyday lives? In her opinion, it should mean that no one is obliged to accept the cultural values of the majority. Next question is about the limits of tolerance as a basis of multi-cultural values. Is every aspect of a cultural diversity worth of respect? Do we tolerate and respect racism and anti-Semitism, or skinhead's actions equally and etc. Helve and other researchers try to find common signs, which characterize the relation of the young generation to multi-cultural values in sociological context (Helve 2006: 103122; Inglehart 2000: 215-228; Skeggs 2004: 75-95):

\footnotetext{
2 Helve, H. 1998. "Unification and Marginalisation of Young People", in Unification and Marginalisation of Young People. Helsinki: Hakapaino Oy; Helve, H. 1999. "Multiculturalism and Values of Young People", Diskus. Internet Journal of Religion 5. Available from Internet: <http://www.uni-marburg.de/religionswissenschaft/journal/diskus $>$ [Last access: 12.01.2009].
} 
The diminishing generation gap and more close spiritual contact with previous generation (not necessarily with parents) are the mark of cultural modernization (Fornäs 1995: 247);

The attitudes and values of young people are in many cases contradictory and nonsystematic $^{3}$;

The same person can consider equality a good thing in a certain context, while expressing very racist opinions in another;

Most young people's attitudes and values are not anchored in any political, religious or other ideology;

They feel free to change their views according to the situation;

A new group of values is strongly connected with globalization process;

The world views of the young generation and the changes in them are an ideological and religious base in the new ecological perspective, which challenges anthropocentrism;

A progressively growing concern with individual peace of mind and small scale micro-narratives came in the place of meta-narratives (Fornäs 1995: 214);

Post-materialist values are to be found among young people and especially among humanists supporting gender and racial equality, cultural differences with equal rights as citizens; they are ready to lower their own standard of living in order to eliminate nuclear power;

Most young people are tolerant and ready to compromise their own standard of living, among other things in order to protect the environment and help those less fortunate.

At the same time, the economic recession and immigration have brought xenophobia back to the forefront of the European agenda. Finland is not an exception, either. Racism and xenophobia are spread among the population in about the same proportion in most of the Nordic countries, according to European opinion polls. Negative attitudes and xenophobia among the main population of Finland towards foreigners are still present and hostility against foreigners has not been completely absent. Such phenomena as violent incidents with racists' motivation or publicly expressed xenophobic opinions are relatively rare. At the same time, actualization of multi-cultural agenda makes non-governmental organizations (NGO), agents, artists, university corpus and students more active in organizing events which praise tolerance, solidarity and multi-cultural values.

\section{Our new values' borders}

The Eastern European countries came to the third millennium in new cultural and social conditions. First of all, the diminishing generation gap and more close spir-

\footnotetext{
3 Amy Gutmann in her book "Identity in Democracy" adds that "no single group identity or even all group identities taken together comprehend the whole of a person", "identity groups are politically significant associations of people who are identified by or identify with one or more shared social markers. Identity groups need not be based on largely unchosen characteristics of persons, such as race or gender" (Gutmann 2003: 1, 8).
} 
itual contact with previous generation are not so typical of mentality of the youth in Eastern European countries. The radical political changes, the struggle for new democracy intensified the generation gap because the world, in which young people grow up, nowadays is measurably different from the world in which generations before them were brought up. Disintegration of traditional moral authorities and values, influence of the global market, greater stress on consumption, changing employment and unemployment status, compression of space and time, and a new instrumentation of relationships among individuals and institutions present new influences and characteristics of the post-modern period (Beck, Beck-Gernsheim 2002). Nation-states lose a lot of their position and status in the face of globalization. At the same time, it is possible to observe the particularistic, ethnic and national-populist movements reflecting the historical repressive experiences in the Baltic States.

Lithuanians are no exception in this respect. As every Eastern European nation, the country has to understand itself in historical perspective, find its own place and way in the processes of European identity formation. Many researchers write about the necessity to find, develop and "distinguish different approaches to European identity in contemporary Lithuanian and European discourses" (Rindzevičiūtè 2002: 78; de Munck 2007; Juknevičius 2005; Liubinienė 2002). The popular idea of "situated national identity" is a reaction to radically new situation in Eastern European countries. To Lithuania as a member of the EU, the borders of which are open for both in and out migration, "situated national identity" offers new possibilities to share its own values and practices with others, and deeper understanding of differences. As Victor C. de Munck concluded, "being a Lithuanian means being able to situate one's own experientially gained knowledge vis-à-vis another and for both parties to recognize each other's perspective in a field of situated common knowledge" (de Munck 2007: 71).

Christian morality and values are a very important component of Lithuanian identity. The slogan "to be Lithuanian means to be Catholic" is popular, "but for the great majority of Lithuanians the meaning of life consists of the happiness of their children and grandchildren, a peaceful and secure future, and other secular values" (Juknevičius 2005: 71). The greatest result of laicization of moral values is permissiveness. For some researchers, it means only "a mere change" of moral system, for some, it is an "undeniable moral decline" (Juknevičius 2005: 75). The slowly growing permissiveness to euthanasia, homosexuality, suicide, abortion and the like is perceived as negative influence of globalization and secularization. In his article "Crisis of the European Identity in Moral and Political Aspect", Vytautas Landsbergis adds that "the unwillingness to investigate the erosion in the value system signifies that Europe has been gradually losing its former sense of identity and values", and "if the European identity is lost, no one can expect to maintain the Lithuanian identity" (Landsbergis 2008). Many Eastern European researchers add a strong relation between identity and values (mostly understood as traditional national values) and its erosion in globalization conditions (Ceplak 2006; Dyczewski 2002; Lewowicki 2000). The fulfillment of a dream about spiritual borders, walls, new mechanism of defending traditional values 
is not easy. For many Eastern European countries religion is an important source of values creation and development. "The impact of living in a society that was historically shaped by once powerful Catholic or Protestant institutions persists today, shaping everyone - Protestant, Catholic or other - who is socialized, into a given nation's culture" (Liubinienè 2002: 54). Religion is this important sphere in which traditional and post-modern values must be identified and discussed in dialogue with believers of other religions and secular part of society. At the same time, it is very important today to find an answer to the following question: what kind of conflicting values will dominate in the condition of new regionalism and territoriality when the borders appear and disappear, become significant, meaningful and meaningless at the same time?

\section{Conclusions}

1. The emergence of a global culture espousing tolerance, moral relativism, and multi-culturalism has been accompanied by a parallel resurgence of traditional ethnic, national, and religious values.

2. The new tendency to weakening the importance of territorial belonging includes two potentially contradictory processes: "border confirming" and "border transcending". New spiritual borders divide not territories, but the cultural domain of values in the same space. What becomes a powerful source of spiritual border's demarcation and disintegration are the values professed by different inhabitants of a unique territory.

3. Multi-culturalism as a socio-political constructs stays today on the stage of searching for innovative theory and practice of managing this process. Nowadays Europe offers several types of alternative models of multi-cultural process management.

4. The EU represents a system of values linking peoples. However, European identity is not a static and close phenomenon which would allow members of the European society agree on common perceptions of themselves and others. The EU itself becomes the area of non-territorial conflicts of values.

5. In the Eastern Europe some multi-cultural values were and are in conflict with traditional national values and become the source of new forms of intolerance and xenophobia.

6. The most noticeable changes in the new generation system of values have place not only in multi-national and for long multi-cultural society but in traditionally, up to now homogenous societies too.

\section{References}

Beck, U.; Beck-Gernsheim, E. 2002. Individualization. London: Sage Publications.

Ceplak, M. M. 2006. "Values of Young People in Slovenia: "The Search for Personal Security", Young 14(4): 291-308.

Deth van, J. W.; Scarbrough, E. 1998a. "The Concept of Values", in J. W. van Deth, E. Scarbrough (Eds.). The Impact of Values, Oxford and New York: Oxford University Press, 21-48. 
Deth van, J. W.; Scarbrough, E. 1998b. "Perspectives on Value Change", in J. W. van Deth, E. Scarbrough (Eds.). The Impact of Values, Oxford and New York: Oxford University Press, $527-540$.

Dyczewski, L. 2002. "Values and Polish Cultural Identity", in L. Dyczewski (Ed.). Values in the Polish Cultural Tradition, Polish Philosophical Studies. Publications of the Council for Research in Values and Philosophy. Available from Internet: <http://www.crvp.org/book/Series04/ IVA-19/chapter_i.htm > [Last access: 12.03.2009].

Flanagan, S. C.; Lee, A.-R. 2003. "The New Politics, Culture Wars, and the Authoritarian-Libertarian Value Change in Advanced Industrial", Comparative Political Studies 36(3): 235-270.

Fornäs, J. 1995. Cultural Theory and Late Modernity. London: Sage Publications.

Gutmann, A. 2003. Identity in Democracy. Princeton, New Jersey: Princeton University Press.

Hannerz, U. 1990. "Cosmopolitans and Locals in World Culture", Theory, Culture \& Society 7: $237-251$.

Helve, H. 1999. "Multiculturalism and Values of Young People", Diskus. Internet Journal of Religion 5. Available from Internet: <http://www.uni-marburg.de/religionswissenschaft/journal/ diskus $>$ [Last access: 12.01.2009].

Helve, H. 2006. "Social Changes and Multicultural Values of Young People", in C. Leccardi, E. Ruspini (Eds.). A New Youth? Young People, Generations and Family Life. Hampshire: Ashgate, 103-122.

Helve, H. 1998. "Unification and Marginalisation of Young People", in Unification and Marginalisation of Young People. Helsinki: Hakapaino Oy.

Human Development Report 2004: Cultural Liberty in Today's Diverse World. 2004. Published for the United Nations Development Programme (UNDP). Available from Internet: <http://hdr. undp.org/en/reports/global/hdr2004> [Last access: 03.12.2008].

Inglehart, R. 2000. “Globalization and Postmodern Values", Washington Quarterly 23(1): 215-228.

Inglehart, R. 1997. Modernization and Postmodernization: Cultural Economic and Political Change in 43 Societies. Princeton, New Jersay: Princeton University Press.

Jagodzinski, W.; Dobbelaere, K. 1998. "Religious and Ethical Pluralism", in J. W. van Deth, E. Scarbrough (Eds.). The Impact of Values, Oxford and New York: Oxford University Press, 218-249.

Juknevičius, S. 2005. „The Religiosity and Morality of Lithuanians in a European Context“, in S. Juknevičius (Ed.). Post-communist Lithuania: Culture in Transition. Vilnius: Culture, Philosophy and Arts Research Institute, 58-86.

Landsbergis, V. 2008. „Europos tapatybės krizė moraliniu ir politiniu požiūriu“, SOTER: Journal of Religious Science 25(53): 145-156.

Lappalainen, S. 2006. "Liberal Multiculturalism and National Pedagogy in a Finnish Preschool Context: Inclusion or Nation-Making?", Pedagogy, Culture \& Society 14 (1): 99-112.

Lewowicki, T. (Ed.). 2000. Edukacja międzykulturowaw Polsce $i$ na świecie. Katowice: Wydawnictwo Uniwersytetu Śląskiego.

Liubinienė, V. 2002. „Vertybių kaita Baltijos šalyse europinès integracijos kontekste“, Sociologija: Mintis ir veiksmas 2(9): 50-60.

Matinheikki-Kokko, K.; Pitkänen, P. 2002. "Immigrant Policies and the Education of Immigrants in Finland", in P. Pitkänen, D. Kalekhin-Fishman, G. K. Verma (Eds.). Education and Im- 
migration: Settlement Policies and Current Challenges. London: Routledge Falmer International Comparative Studies in Education, 48-73.

Munck de, V. C. 2007. "First, Second and Finally Third Order Understandings of Lithuanian National Identity: An Anthropological Approach”, Sociologija: Mintis ir veiksmas 1(19): 51-73.

Rindzevičiūtė, E. 2002. „Europietiškumo problema diskusijose apie lietuvišką nacionalinị identitetą“, Sociologija: Mintis ir veiksmas 2(9): 61-80.

Skeggs, B. 2004. "Exchange, Value and Affect: Bourdieu and "the Self”, Sociological Review 52 (2): 75-95.

Vertovec, S.; Wessendorf, S. 2004. Migration and Cultural, Religious and Linguistic Diversity in Europe: An Overview of Issues and Trends. Netherlands: IMISCOE Publications.

\section{DAUGIAKULTŪRĖS VERTYBĖS IR RIBOS}

\section{Basia Nikiforova}

\section{Santrauka}

Daugiakultūriškumas apžvelgiamas kaip konceptas, labiau grindžiamas prielaidomis, o ne žiniomis; iteisinamas diskursu, o ne teise. Daugiakultūriškumas kaip socio-politinis konstruktas nèra vien tik daugiakultūrè ir daugiareligé mozaika - jam būdingos savarankiškos vertybès. Naujos sienos Europos Sajungoje (ES) yra neteritorinès, jos įtvirtina naują paradigmą, pagrịstą konkretaus teritorinio veiksnio susilpnejjimu. Mūsų dienomis vertybès tampa vis svarbesniu demarkacijos šaltiniu. Šio straipsnio tikslas - iškelti daugiakultūriškumo problemą ir jo itaką tapatumui bei vertybių suvokimui naujoje Europos situacijoje, kai sienos tèra simbolinès. Daugiakultūriškumas - tai etnocentrinès tradicijos perkainojimas ir kūrimas tokių post-materialistinių vertybių, kaip individuali saviraiška, asmeninė transformacija, atvirumas ir solidarumas, lytinè ir rasinè lygybè, didesnè tolerancija etniniam, kultūriniam ir religiniam skirtingumui.

Reikšminiai žodžiai: daugiakultūriškumas, daugiakultūrès strategijos, daugiakultūrès vertybès, religinès ribos, religinis pliuralizmas.

Received 12 January 2009, accepted 30 March 2009 